\title{
Hybrid Bis-Histidine Phenanthroline-Based Ligands to Lessen $A \beta$-Bound Cu ROS Production: An Illustration of Cu(I) Significance
}

\author{
Marielle Drommi (D), Clément Rulmont $(\mathbb{D}$, Charlène Esmieu (i) and Christelle Hureau * \\ CNRS, LCC (Laboratoire de Chimie de Coordination), 205 Route de Narbonne, CEDEX 4, 31077 Toulouse, France; \\ marielle.drommi@lcc-toulouse.fr (M.D.); clement.rulmont@lcc-toulouse.fr (C.R.); \\ charlene.esmieu@lcc-toulouse.fr (C.E.) \\ * Correspondence: christelle.hureau@lcc-toulouse.fr
}

\begin{abstract}
We here report the synthesis of three new hybrid ligands built around the phenanthroline scaffold and encompassing two histidine-like moieties: phenHH, phenHGH and $\mathrm{H}^{\prime}$ phenH', where $\mathrm{H}$ correspond to histidine and $\mathrm{H}^{\prime}$ to histamine. These ligands were designed to capture $\mathrm{Cu}(\mathrm{I} / \mathrm{II})$ from the amyloid- $\beta$ peptide and to prevent the formation of reactive oxygen species produced by amyloid- $\beta$ bound copper in presence of physiological reductant (e.g., ascorbate) and dioxygen. The amyloid- $\beta$ peptide is a well-known key player in Alzheimer's disease, a debilitating and devasting neurological disorder the mankind has to fight against. The $\mathrm{Cu}-\mathrm{A} \beta$ complex does participate in the oxidative stress observed in the disease, due to the redox ability of the $\mathrm{Cu}(\mathrm{I} / \mathrm{II})$ ions. The complete characterization of the copper complexes made with phenHH, phenHGH and $\mathrm{H}^{\prime} \mathrm{phenH}^{\prime}$ is reported, along with the ability of ligands to remove $\mathrm{Cu}$ from $\mathrm{A} \beta$, and to prevent the formation of reactive oxygen species catalyzed by $\mathrm{Cu}$ and $\mathrm{Cu}-\mathrm{A} \beta$, including in presence of zinc, the second metal ions important in the etiology of Alzheimer's disease. The importance of the reduced state of copper, $\mathrm{Cu}(\mathrm{I})$, in the prevention and arrest of ROS is mechanistically described with the help of cyclic voltammetry experiments.
\end{abstract}

Keywords: Alzheimer's disease; copper; amyloid- $\beta$; ROS production; peptide; phenanthroline

\section{Introduction}

Alzheimer's disease (AD) is the most common form of senile dementia, causing loss of autonomy, and affecting around 50 million people worldwide, mainly people over 60 [1]. Since the world population is aging, the social and economic consequences of this disease are expected to increase: related costs are to soar up to 2 trillion US\$ by 2030 [2]. This neurodegenerative disease is characterized by different pathological markers, including extracellular deposits of amyloid- $\beta$ peptide $(A \beta)$ aggregates denominated as senile plaques, metal ions dyshomeostasis and an overall oxidative stress [3-10]. A $\beta$ is a 40 to 42 aminoacid residues peptide, made of a hydrophilic N-terminus, with amino-acid residues able to bind metal ions, and a hydrophobic C-terminus part prone to aggregate (Scheme 1a). The interaction between $A \beta$ and metal ions has been extensively studied, and it has been shown that $A \beta$ can bind metal ions, especially $C u, Z n$ and Fe ions [6,11-20]. In particular, copper is a redox-active metal, able to cycle between two biologically relevant redox states: $\mathrm{Cu}(\mathrm{I})$ and $\mathrm{Cu}(\mathrm{II})$. $\mathrm{Cu}(\mathrm{II})$ can be reduced by various reductants (e.g., ascorbate) and $\mathrm{Cu}(\mathrm{I})$ can be incompletely oxidized by dioxygen in stepwise single-electron transfer, leading to the formation of reactive oxygen species (ROS), such as $\mathrm{O}_{2}^{\bullet-}, \mathrm{HO}^{\bullet}, \mathrm{H}_{2} \mathrm{O}_{2}$ and hence participating to oxidative stress [3,7,21-23]. In a healthy brain, their concentrations are strictly regulated by dedicated enzymes, including $\mathrm{Cu}$ enzymes in which the environment (and thus, the redox state) of $\mathrm{Cu}$ is tightly controlled [24,25]. However, in AD, brain tissues are damaged by oxidative stress, in link to the high-concentration of "loosely-bound" $\mathrm{Cu}$ in $A \beta$ aggregates (Scheme 1b) [25]. 
(a)

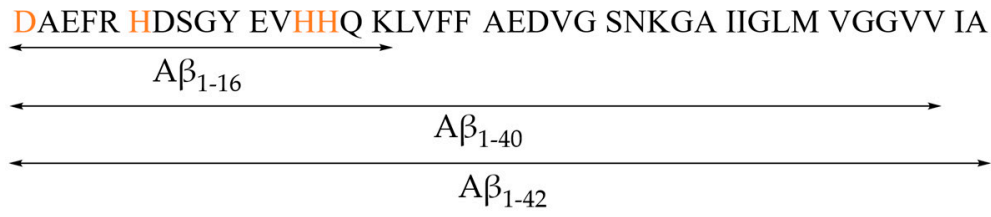

(b)

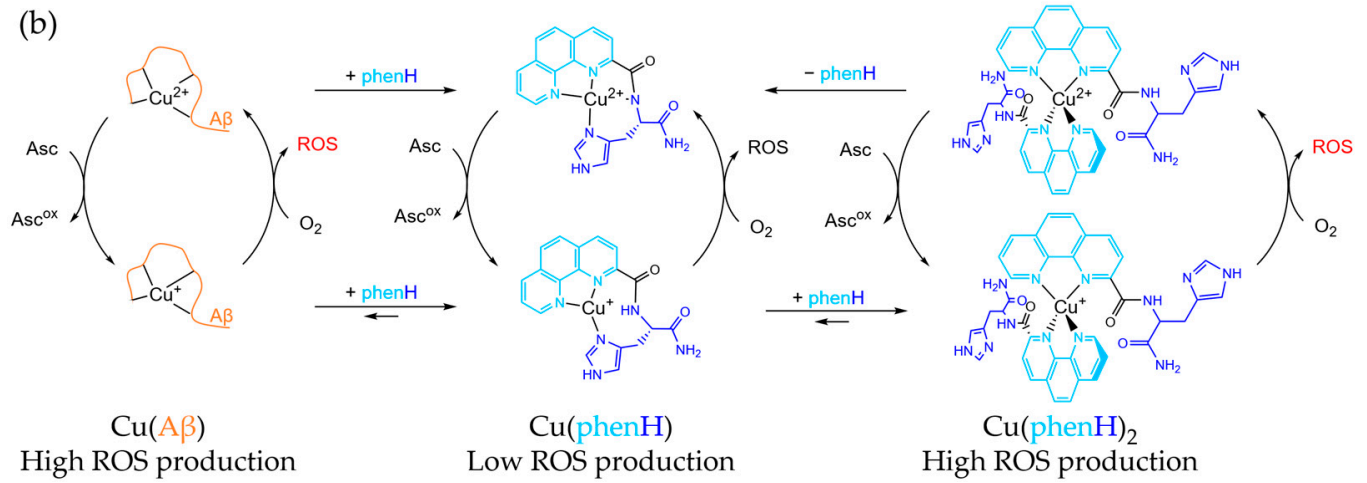

Scheme 1. (a) Sequence of $A \beta$ peptide. The main metal binding amino acids are colored in orange. (b) Simplified mechanism of $\mathrm{CuA} \beta, \mathrm{Cu}(\mathrm{phenH})$ and $\mathrm{Cu}(\mathrm{phenH})_{2}$ redox cycling reactions, with structure of $\mathrm{Cu}(\mathrm{II})(\mathrm{phenH})$ and proposed structures of $\mathrm{Cu}(\mathrm{I})(\mathrm{phenH})$ and $\mathrm{Cu}(\mathrm{I} / \mathrm{II})(\mathrm{phenH})_{2}$.

To address the deleterious effects of $\mathrm{Cu}$-bound $\mathrm{A} \beta$, a large number of ligands has been developed. These ligands should combine many properties to be considered as potential therapeutic molecules [15,26-28]. Thermodynamically, they should be able to remove $\mathrm{Cu}$ from $\mathrm{A} \beta$, which means that they must have a higher affinity for $\mathrm{Cu}(\mathrm{II})$ or $\mathrm{Cu}(\mathrm{I})$ than $\mathrm{A} \beta$ (10 ${ }^{10} \mathrm{M}^{-1}$ at $\mathrm{pH} 7.4[14,29]$ or $10^{7} \mathrm{M}^{-1}-10^{10} \mathrm{M}^{-1}$ [30-32], respectively), but this affinity should not be too high, to avoid removing $\mathrm{Cu}$ from essential metalloenzymes and disrupt $\mathrm{Cu}$ homeostasis [24,33]. The complex formed by the ligand with $\mathrm{Cu}$ should be stable in its redox state, $\mathrm{Cu}(\mathrm{I})$ or $\mathrm{Cu}(\mathrm{II})$, not to form ROS on its own. The ligand should also be selective for $\mathrm{Cu}$ against $\mathrm{Zn}$ [34], especially since $\mathrm{Zn}$ is more abundant than $\mathrm{Cu}$ in the synaptic cleft (1-10 $\mu \mathrm{M}$ for $\mathrm{Cu}$ and 10-300 $\mu \mathrm{M}$ for $\mathrm{Zn}$ under neuronal excitation $[10,35,36])$. Furthermore, the kinetics of complex formation between the ligand and $\mathrm{Cu}$ has to be fast, to prevent efficiently ROS formation [37]. Finally, the ligand should respect the criteria linked to therapeutic applications: it should be stable in vivo (especially at different $\mathrm{pH}$ ), fulfill pharmacokinetics properties, and be able to cross the brain blood barrier [27].

One particular ligand has drawn the attention on the fact that it is important to consider both $\mathrm{Cu}(\mathrm{II})$ and $\mathrm{Cu}(\mathrm{I})$ chelation to the ligand and the respective speciation [38]. This ligand, named phenH, is composed of a peptide-like scaffold, with a histidine linked to a phenanthroline in position 2 , and an amide at the C-terminus. This ligand is able to chelate $\mathrm{Cu}(\mathrm{II})$ in a distorted square-planar coordination, with the phenanthroline, the deprotonated amide of the peptide bond and the imidazole ring [39]. When added in a 1:1 ratio against $\mathrm{Cu}$, phen $\mathrm{H}$ is able to slow ROS production, in absence and in presence of $\mathrm{A} \beta$, being a good candidate as chelator. However, strikingly, when phenH is added at higher ratio ( 2 equivalents against $\mathrm{Cu}$ ), its ability to slow ROS production is lowered: usually, the more ligand is added, the slower is the ROS production, because there is less redox active loosely-bound copper [40]. To explain this unexpected phenomenon, the following mechanism has been proposed: when phenH is in excess, a $\mathrm{Cu}(\mathrm{I})(\text { phenH})_{2}$ complex is formed during the redox cycling, with $\mathrm{Cu}(\mathrm{I})$ being chelated by two phenanthroline moieties in a tetrahedral fashion (Scheme $1 b$ ). This 1:2 complex is redox active, and thus is less efficient in preventing ROS production. This effect is alleviated by the addition of $\mathrm{Zn}$ (II), because association constant of $\mathrm{Zn}(\mathrm{II})(\mathrm{phenH})$ is lower than the one of $\mathrm{Cu}(\mathrm{II})(\mathrm{phenH})$ but higher than the one of $\mathrm{Cu}(\mathrm{I})(\mathrm{phenH})_{2}$, so $\mathrm{Zn}(\mathrm{II})$ can take over the excess of ligand, preventing the formation of the 1:2 complex [38].

The aim of the present work was to optimize phenH, with new generation of phenanthroline-based peptide scaffolds, that would less be able to create this 1:2 com- 
plex, and thus could avoid ROS production even in excess of ligand. To enlarge the family of phenanthroline-based ligands, we designed the set of molecules presented below (Scheme 2). PhenHH (resp. phenHGH) is made of a phenanthroline moiety appended with a peptide sequence of two adjacent histidines (resp. histidine-glycine-histidine fragment). Finally, $\mathrm{H}^{\prime}$ phen $\mathrm{H}^{\prime}$ is a symmetrical version of phenH, but with histamines instead of histidines, for synthetic reasons. PhenH was kept in the set of studied molecules as a reference. These ligands were rationally designed following two hypothesis:

- Increasing the sterical hindrance of the side chains of the phenanthroline would prevent the formation of the $\mathrm{Cu}(\mathrm{I})(\mathrm{phen})_{2}$ complex, responsible for ROS production.

- The addition of the second imidazole moiety would allow the formation of a 1:1 tetrahedral $\mathrm{Cu}(\mathrm{I})$ complex, with the metal being bound by the phenanthroline and both imidazole moiety, and this complex would be more thermodynamically favorable than $\mathrm{Cu}(\mathrm{I})(\text { phen })_{2}$ complex.<smiles>NC(=O)[C@H](Cc1c[nH]cn1)NC(=O)c1ccc2ccc3cccnc3c2n1</smiles><smiles>NC(=O)[C@H](Cc1c[nH]cn1)NC(=O)CNC(=O)[C@H](Cc1c[nH]cn1)NC(=O)c1ccc2ccc3cccnc3c2n1</smiles><smiles>NC(=O)[C@H](Cc1c[nH]cn1)NC(=O)[C@H](Cc1c[nH]cn1)NC(=O)c1ccc2ccc3cccnc3c2n1</smiles>

Scheme 2. Structures of the studied ligands.

Herein, we report the complete characterization of the $\mathrm{Cu}(\mathrm{II})$ complexes made with these ligands, their ability to stop ROS production, and an electrochemical study of the ligands in the presence of $\mathrm{Cu}$.

\section{Results and Discussion}

\subsection{Synthesis of the Ligands}

Asymmetrical ligands phenH, phenHH and phenHGH were synthesized from their carboxylic acid precursor (Scheme S1): 2-carboxy-1,10-phenanthroline, which was synthesized according to a described procedure [41]. 1,10-phenanthroline was activated as an $\mathrm{N}$-oxide through oxidation by hydrogen peroxide in acidic conditions. A nucleophilic aromatic substitution in presence of cyanide and benzoyl chloride led to 2-cyano-1,10phenanthroline. Finally, the hydrolysis of the nitrile in basic medium led to 2-carboxy1,10-phenanthroline.

To yield the ligands phenH, phenHH and phenHGH, the amino-acids chain was first grafted to a rink amide resin via solid phase peptide synthesis (SPPS) standard protocol [42]. Briefly, fluorenylmethoxycarbonyl (Fmoc)-protected resin was deprotected using 20\% piperidine in dimethylformamide (DMF), and the loading of the resin was calculated by UV-vis titration of the dibenzofulvene-piperidine adduct [43]. Fmoc-protected amino acids were coupled using hydroxybenzothiazole (HOBt) and (2-(1H-benzotriazol-1-yl)-1,1,3,3tetramethyluronium hexafluorophosphate (HBTU) as activators and diisopropylethylamine 
(DIPEA) as base. 2-carboxy-1,10-phenanthroline was then coupled using benzotriazol-1yloxytripyrrolidinophosphonium hexafluorophosphate (PyBOP) as activator, which gave better yields than HBTU [39]. Finally, the ligand was cleaved from the resin in acidic medium, and purified by reverse phase chromatography.

Symmetrical ligand $\mathrm{H}^{\prime}$ phen $\mathrm{H}^{\prime}$ was synthesized from the dicarboxylic acid precursor: 2,9-dicarboxy-1,10-phenanthroline, which was synthesized according to a described protocol [44]. 2,9-dimethyl-1,10-phenanthroline was oxidized to the dialdehyde with selenium dioxide, and then oxidized again to the dicarboxylic acid in nitric acid. It was first tried to couple the diacid precursor to two histidines at the same time, using SPPS, but probably because of the distance between two histidines grafted on the resin, this method gave very low yields (approx. 2\%). The solution phase peptide coupling strategy was thus adopted ( $57 \%$ yield), and histamine was used instead of histidine as the amine, for synthesis simplicity reasons. Ligand $\mathrm{H}^{\prime}$ phenH' was synthesized according to a described protocol [45]: treatment of 2,9-dicarboxy-1,10-phenanthroline with carbonyldiimidazole (CDI) led to the corresponding activated ester, to which was added histamine to yield $\mathrm{H}^{\prime} \mathrm{phenH}^{\prime}$.

\subsection{Speciation of the $\mathrm{Cu}(\mathrm{II})$ Complexes}

To determine the structures and speciation of the $\mathrm{Cu}$ (II) complexes, UV-visible and electron paramagnetic resonance (EPR) spectroscopies were used.

- Firstly, the ligands were studied in the presence of 1 equivalent of $\mathrm{Cu}(\mathrm{II})$, to determine the structure of the complexes $\mathrm{Cu}(\mathrm{II}) \mathrm{L}\left(\mathrm{L}=\right.$ phenH, phenHH, phenHGH and $\mathrm{H}^{\prime}$ phenH unless otherwise stated). For phenH, phenHH and phenHGH, the UV-visible spectra overlap (Figure 1a), the three complexes have comparable $\lambda_{\max }{ }^{\mathrm{d}-\mathrm{d}}$ and $\varepsilon$ values (Table 1). Furthermore, their EPR signatures are overlapping as well: they have same values of the characteristic EPR g-factors and hyperfine coupling constants. This indicates that the coordination sphere of $\mathrm{Cu}$ (II) inside phenHH and phenHGH is virtually identical to that in phenH. The latter was determined previously with its crystal structure [38]. A coordination mode for $\mathrm{Cu}(\mathrm{II})(\mathrm{phenHH})$ and $\mathrm{Cu}(\mathrm{II})(\mathrm{phenHGH})$ could thus be proposed on this basis (Scheme $\mathrm{S} 2 \mathrm{a}, \mathrm{d}$ ). For $\mathrm{H}^{\prime} \mathrm{phenH}^{\prime}$, it can be noticed that the EPR signature of $\mathrm{Cu}(\mathrm{II})\left(\mathrm{H}^{\prime}\right.$ phen $\left.\mathrm{H}^{\prime}\right)$ is significantly different from the signature of $\mathrm{Cu}(\mathrm{II})(\mathrm{phenH})$ as mainly mirrored by different $\mathrm{A} / /$ values (Table 1 ). In addition, the $\mathrm{d}-\mathrm{d}$ transition band is redshifted: the coordination sphere of $\mathrm{Cu}(\mathrm{II})$ inside $\mathrm{H}^{\prime}$ phenH $\mathrm{H}^{\prime}$ is thus different from the one in phenH, phenHH and phenHGH. The redshift of the $\mathrm{d}-\mathrm{d}$ transition band suggests the decoordination of the deprotonated amide ligand [46], while the $\varepsilon$ value indicates that mainly nitrogen atoms are bound to the $\mathrm{Cu}(\mathrm{II})$. The EPR parameters values are also in line with a $4 \mathrm{~N}$ coordination, according to Peisach-Blumberg correlation $[47,48]$. On this basis, a structure for $\mathrm{Cu}(\mathrm{II})\left(\mathrm{H}^{\prime}\right.$ phenH') complex has been proposed (Scheme S2g), where the metal ion is chelated by the phenanthroline and both imidazole rings.

- In a second time, the possibility to form the $\mathrm{Cu}(\mathrm{II}) \mathrm{L}_{2}$ complex was investigated by EPR spectroscopy, for phenHH, phenHGH and $\mathrm{H}^{\prime}$ phenH'. EPR spectra of $\mathrm{Cu}$ (II) in presence of 1 and 2 equivalents of ligands were monitored (Figure S1). The EPR signatures of $\mathrm{Cu}(\mathrm{II})$ in these two conditions are the same, for all the ligands: the $\mathrm{Cu}(\mathrm{II}) \mathrm{L}_{2}$ species are not detected, in line with the previously published data [38].

- Finally, the behavior of the ligands in the presence of more equivalents of $\mathrm{Cu}(\mathrm{II})$ was investigated. EPR spectra of phenHH in presence of 2 equivalents of $\mathrm{Cu}(\mathrm{II})$ has been performed (Figure S2a), and shows the superimposition of a remaining contribution from the signature of the 1:1 species and a broad and weak signal (better seen with modifying the recording conditions, spectrum noted with a $(*))$. This suggests the formation of a binuclear copper complex, with two close $(<7 \AA)$ paramagnetic centers, leading to the disappearance of EPR signal due to magnetic interactions [24]. In UV-visible spectroscopy, a weak redshift in the d-d absorption wavelength is observed as well as a $30 \%$ increase in the absorbance in presence of 2 equivalents of $\mathrm{Cu}$ (II) (Figure S2b, Table S1). This indicates that the second $\mathrm{Cu}(\mathrm{II})$ ion may be bound by 
water molecule as well as the two remaining nitrogen-donor atoms of phenHH [46,49]. On this basis, different structures have been proposed, such as $\mathrm{Cu}_{2}$ (phenHH), with a second copper being likely bound between the imidazole of the second histidine and the deprotonated amide of the peptide bond [50,51] (Scheme S2b). Other structures have been considered as well for intermediate $\mathrm{Cu}$ :phenHH ratio, such as a $\mathrm{Cu}_{3}(\text { phenHH })_{2}$ complex (Scheme S2c). These suggestion are in line with the observation made during the titrations of the ligands by $\mathrm{Cu}$ (II) (Figure S3). In fact for phenHH, two slope breaks were observed, suggesting the formation of species with stoichiometry in $\mathrm{Cu}(\mathrm{II})$ higher than 1:1.

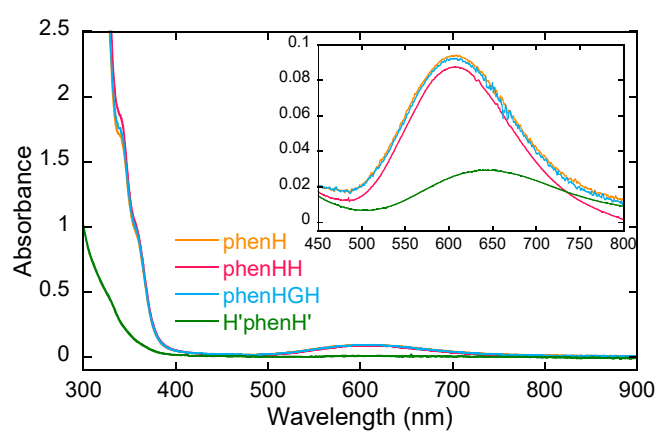

(a)

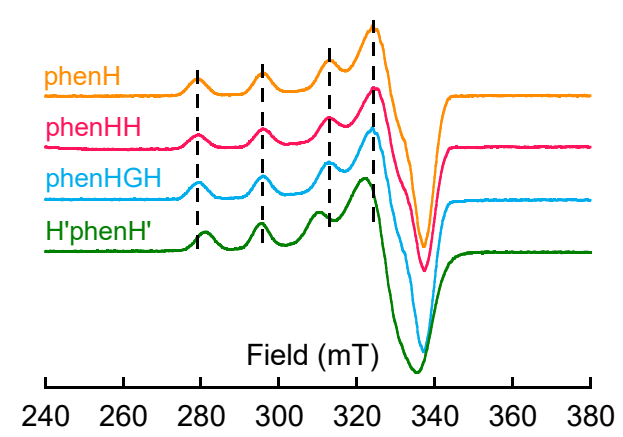

(b)

Figure 1. (a) UV-visible spectra of the ligands with 1 equivalent of $\mathrm{Cu}(\mathrm{II})$. [phenH] $=[\mathrm{phenHH}]=$ [phenHGH] $=0.8 \mathrm{mM},\left[\mathrm{H}^{\prime}\right.$ phenH'] $=0.25 \mathrm{mM}$, [HEPES $]=100 \mathrm{mM}, \mathrm{pH}$ 7.1. (b) $9 \mathrm{GHz}$-band EPR spectra of $\mathrm{Cu}(\mathrm{II})$ with 1 equivalent of the ligands. [Cu] $=500 \mu \mathrm{M}(\mathrm{Cu}$ isotopes in natural abundance), [ligand] $=500 \mu \mathrm{M},[$ HEPES $]=50 \mathrm{mM}, \mathrm{pH} 7.4,10 \%$ of glycerol as cryoprotectant. Attenuation $=16 \mathrm{~dB}$ and amplitude modulation $=5 \mathrm{G}$.

Table 1. UV-visible ( $\varepsilon$ are calculated by dividing absorbance at $\lambda_{\max }{ }^{\mathrm{d}-\mathrm{d}}$ by $\mathrm{Cu}(\mathrm{II})$ concentration but are not representative of a certain complex, since more than one complex may be in solution) and EPR parameters of the ligands in presence of 1 equivalent of $\mathrm{Cu}(\mathrm{II})$.

\begin{tabular}{|c|c|c|c|c|}
\hline Complex & UV-Vis Parameters & & EPR Parameters & \\
\hline & $\lambda_{\max }{ }^{\mathrm{d}-\mathrm{d}}(\mathrm{nm})\left(\varepsilon\left(\mathrm{M}^{-1} \mathrm{~cm}^{-1}\right)\right.$ & $g_{/ /}$ & $\left|A_{/ /}\right|\left(10^{-4} \mathrm{~cm}^{-1}\right)$ & $g_{\perp}$ \\
\hline $\mathrm{Cu}(\mathrm{II})($ phenH) & $608(117)$ & 2.21 & 178 & 2.05 \\
\hline $\mathrm{Cu}(\mathrm{II})($ phenHH$)$ & 607 (109) & 2.22 & 176 & 2.05 \\
\hline $\mathrm{Cu}(\mathrm{II})($ phenHGH) & $605(115)$ & 2.22 & 176 & 2.05 \\
\hline $\mathrm{Cu}(\mathrm{II})\left(\mathrm{H}^{\prime}\right.$ phenH') & $642(117)$ & 2.23 & 151 & 2.06 \\
\hline
\end{tabular}

For phenHGH and $\mathrm{H}^{\prime}$ phenH', similar observations can be made (Figures S2 and S3, Table S1): hypothetical structures for $\mathrm{Cu}(\mathrm{II})_{2}$ (phenHGH), $\mathrm{Cu}(\mathrm{II})_{3}(\text { phenHGH })_{2}$ and $\mathrm{Cu}(\mathrm{II})_{2}$ $\left(\mathrm{H}^{\prime}\right.$ phenH') have been proposed on this basis (Scheme S2e,f,h).

On the contrary for phenH, the EPR spectra performed in presence of 2 equivalents of $\mathrm{Cu}$ (II) does not show any weakening of the signal (Figure S2a), suggesting that no binuclear complex is formed with phenH in excess of copper. Furthermore, the UV-visible spectra of phenH with 2 equivalents of copper does not show any shift of the d-d absorption wavelength, but the precipitation of $\mathrm{Cu}$ (II) (overall absorbance increase, Figure S2b), due to the poor solubility of free $\mathrm{Cu}(\mathrm{II})$ in HEPES buffer.

\subsection{Ability of the Ligands to Extract $\mathrm{Cu}(\mathrm{II})$ from $A \beta$}

The ligands were then tested for their ability to extract $\mathrm{Cu}(\mathrm{II})$ from the $\mathrm{A} \beta$ peptide. EPR spectra of $\mathrm{Cu}(\mathrm{II})$ in the presence of 1 equivalent of the ligands and 1 equivalent of $\mathrm{A} \beta$ were realized, with and without $\mathrm{Zn}(\mathrm{II})$. 
For phenHH and phenHGH (Figure $\mathrm{S} 4 \mathrm{a}, \mathrm{b}$ ), the EPR signature of $\mathrm{Cu}$ (II) in presence of the ligands, $A \beta$ and with or without $\mathrm{Zn}(\mathrm{II})$ is identical to the one of $\mathrm{Cu}(\mathrm{II})$ in presence of the ligands. This means that the affinity of $\mathrm{Cu}$ (II) for the ligands is higher than the one of $\mathrm{Cu}$ (II) for $\mathrm{A} \beta$, and that the ligand is selective for $\mathrm{Cu}(\mathrm{II})$ vs. $\mathrm{Zn}(\mathrm{II})$ in presence of $\mathrm{A} \beta$.

On the contrary for H'phenH' (Figure S4c), two species can be seen in the EPR spectra in the presence of $\mathrm{H}^{\prime}$ phen $\mathrm{H}^{\prime}$ and $\mathrm{A} \beta$ : a majority of $\mathrm{Cu}(\mathrm{II})\left(\mathrm{H}^{\prime}\right.$ phen $\left.\mathrm{H}^{\prime}\right)$ and a minority of $\mathrm{Cu}(\mathrm{II}) \mathrm{A} \beta$ (in an approximatively $7 / 3$ ratio). The affinity constants of $\mathrm{Cu}(\mathrm{II})\left(\mathrm{H}^{\prime} \mathrm{phenH}^{\prime}\right)$ and $\mathrm{Cu}(\mathrm{II}) \mathrm{A} \beta$ are thus in the same order of magnitude. The addition of $\mathrm{Zn}$ (II) does not displace this equilibrium. It is then anticipated that ROS production will less be slowed by $\mathrm{H}^{\prime}$ phen $\mathrm{H}^{\prime}$ in the presence of $\mathrm{A} \beta$.

\subsection{Ability of the Ligands to Stop Cu-Induced ROS Production}

In order to study and quantify the copper-induced ROS production, an experiment based on ascorbate consumption has been used [52,53]. Indeed, ascorbate concentration can be measured by UV-visible spectroscopy by monitoring absorbance at $265 \mathrm{~nm}$ $\left(\varepsilon=14,500 \mathrm{M}^{-1} \mathrm{~cm}^{-1}\right)$. This is a straightforward method, which compares well with fluorescence-based ROS detection method [14,52,54-56]. In presence of copper, dioxygen, ascorbate and other species (such as $A \beta$ peptide or potential drug candidates), the ascorbate consumption rate will provide information on ROS production rate, and thus on oxidative stress produced in this environment.

The ligands have thus been challenged to stop ROS production, in absence and in presence of $\mathrm{A} \beta$ and/or $\mathrm{Zn}(\mathrm{II})$. First, the global behavior of ligand phenHH, phenHGH and $\mathrm{H}^{\prime}$ phenH' is similar to the one of phenH (Figure 2 and Figure S5): in absence of $\mathrm{Zn}$ (II) (without or with $\mathrm{A} \beta$ ), the ligands slow down the $\mathrm{Cu}$-induced ascorbate consumption more efficiently when added at 1.2 equivalent than 2 equivalents, suggesting that the mechanism described before applies here as well (i.e., formation of a $\mathrm{Cu}(\mathrm{I}) \mathrm{L}_{2}$ complex able to redox cycle, Scheme $1 b$ ). The addition of $\mathrm{Zn}(\mathrm{II})$ prevents the formation of the $\mathrm{Cu}(\mathrm{I}) \mathrm{L}_{2}$ complex by competing for ligand binding and thus give back the ligands the ability to lessen ROS production. These results show that the crowding brought by the His-His, His-Gly-His or bis-histamine moieties is not enough to preclude formation of the redox active $\mathrm{Cu}(\mathrm{I}) \mathrm{L}_{2}$ complex.

It is however interesting to compare the different ligands side by side to evaluate their performance. First concentrating on the complex $\mathrm{CuL}$ in a 1:1 ratio (Figure 2c, dark blue bars), ligands phenH, phenHH and phenHGH exhibit similar ascorbate consumption rates $\left(4.4 \pm 0.2 \mathrm{nM} \mathrm{s}^{-1}\right.$ for phenH, $4.91 \pm 0.04 \mathrm{nM} \mathrm{s}^{-1}$ for phenHH and $5.4 \pm 0.6 \mathrm{nM} \mathrm{s}^{-1}$ for phenHGH). This is in line with the similarity of the coordination sphere of $\mathrm{Cu}(\mathrm{II})$ in these ligands, as shown earlier (Schemes $1 \mathrm{~b}$ and S2a,d)): $\mathrm{Cu}(\mathrm{II})$ is tightly bound in a square-planar coordination, unable to cycle back to $\mathrm{Cu}(\mathrm{I})$ and produce ROS. In contrast, for $\mathrm{H}^{\prime}$ phenH' the ascorbate consumption is much faster $\left(11.6 \pm 0.3 \mathrm{nM} \mathrm{s}^{-1}\right)$ : this may be explained by the coordination sphere of $\mathrm{H}^{\prime}$ phenH' around $\mathrm{Cu}(\mathrm{II})$ (Scheme S2g), where the metal ion is more loosely bound (with three adjacent metallacycles of $(9,5,9)$ members vs. $(5,5,6)$ for phenH, phenHH and phenHGH [50]). This more flexible environment may provide $\mathrm{Cu}(\mathrm{I}) / \mathrm{Cu}(\mathrm{II})$ redox active species. This trend is also observed regardless the Cu:L stoichiometry. In presence of $A \beta$, the ascorbate consumption rate is also higher than for the other three ligands; this may be due to the only partial removal of $\mathrm{Cu}(\mathrm{II})$ from $\mathrm{A} \beta$ by $\mathrm{H}^{\prime}$ phenH'. 

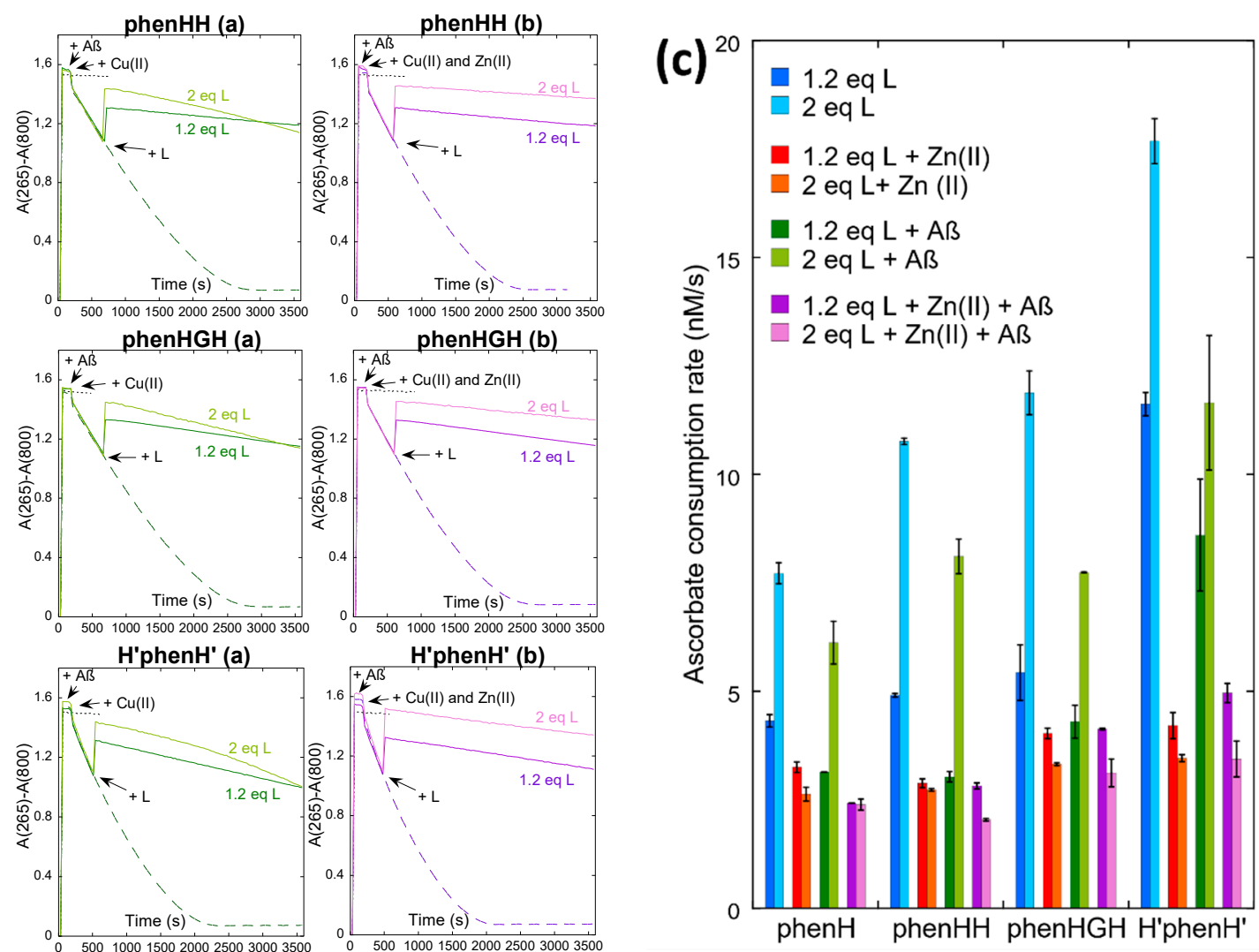

Figure 2. Kinetics of ascorbate consumption, starting from a mixture of $\mathrm{Cu}(\mathrm{II})$ and $\mathrm{Cu}(\mathrm{I})$, with $\mathrm{A} \beta$, without (a) or with (b) Zn(II), without (dashed line) or with (plain line) 1.2 or 2 equivalents of L (ligand), followed by UV-vis spectroscopy at $265 \mathrm{~nm}$ with a background correction at $800 \mathrm{~nm}$. [AscH $\left.{ }^{-}\right]=100 \mu \mathrm{M},[\mathrm{Cu}]=10 \mu \mathrm{M},[\mathrm{A} \beta]=[\mathrm{Zn}]=12 \mu \mathrm{M},[\mathrm{L}]=12 \mathrm{or}$ $20 \mu \mathrm{M}$, [HEPES] = $100 \mathrm{mM}$, pH 7.1. Black dotted lines indicate the control experiment with ascorbate only. (c) Ascorbate consumption rate, between 2000 and $3000 \mathrm{~s}$, calculated by dividing the slope of the variation of absorbance by the extinction coefficient of ascorbate, $\varepsilon_{265 \mathrm{~nm}}=14,500 \mathrm{M}^{-1} \mathrm{~cm}^{-1}$. Data are means $\pm S$.D. Measurements were performed on at least two independent experiments $(n=2 / 3)$.

In the presence of $\mathrm{Zn}(\mathrm{II})$, the ascorbate consumption rate is similar for all four ligands. For phenH, phenHH and phenHGH, it is not very different from the rate in absence of $\mathrm{Zn}$ (II) with 1 equivalent of ligand, showing that these 3 ligands are selective for $\mathrm{Cu}(\mathrm{II})$. However for $\mathrm{H}^{\prime}$ phenH', the addition of $\mathrm{Zn}(\mathrm{II})$ divides the rate by more than a factor 2 (11.6 $\pm 0.3 \mathrm{nM} \mathrm{s}^{-1}$ without $\mathrm{Zn}(\mathrm{II}), 4.2 \pm 0.3 \mathrm{nM} \mathrm{s}^{-1}$ with $\mathrm{Zn}(\mathrm{II})$ ). To explain the positive effect of $\mathrm{Zn}(\mathrm{II})$ in this situation, it is hypothesized that $\mathrm{H}^{\prime}$ phenH' has a similar affinity for $\mathrm{Zn}$ (II) than for $\mathrm{Cu}(\mathrm{II})$, and thus binds to $\mathrm{Zn}$ (II), in part. As demonstrated previously, $\mathrm{H}^{\prime}$ phen $\mathrm{H}^{\prime}$ is able to bind two $\mathrm{Cu}(\mathrm{II})$ ions ( $\mathrm{N}$ from the phenanthroline, from the amide and from the imidazole, Scheme S2h). We thus propose the following reaction:

$$
2 \mathrm{Cu}(\mathrm{II})\left(\mathrm{H}^{\prime} \mathrm{phenH} \mathrm{H}^{\prime}\right)+\mathrm{Zn}(\mathrm{II}) \rightleftarrows \mathrm{Cu}(\mathrm{II})_{2}\left(\mathrm{H}^{\prime} \mathrm{phenH}^{\prime}\right)+\mathrm{Zn}(\mathrm{II})\left(\mathrm{H}^{\prime} \mathrm{phenH}^{\prime}\right)
$$

This hypothesis is supported by the EPR spectra of $\mathrm{Cu}(\mathrm{II})$ in the presence of $\mathrm{H}^{\prime}$ phen $\mathrm{H}^{\prime}$ and $\mathrm{Zn}(\mathrm{II})$ (Figure S6): when adding 1 equivalent of $\mathrm{Zn}(\mathrm{II})$ to a solution of $\mathrm{Cu}\left(\mathrm{H}^{\prime} \mathrm{phenH} \mathrm{H}^{\prime}\right)$, the EPR spectra is the overlay of the spectra of $\mathrm{Cu}(\mathrm{II})\left(\mathrm{H}^{\prime} \mathrm{phenH}^{\prime}\right)$ at approximately $65 \%$, and of a broad spectra, similar to the one obtained for $\mathrm{Cu}(\mathrm{II})_{2}\left(\mathrm{H}^{\prime}\right.$ phenH') (Figure $\left.\mathrm{S} 3 \mathrm{~b}\right)$. In the $\mathrm{Cu}(\mathrm{II})_{2}\left(\mathrm{H}^{\prime}\right.$ phenH') coordination mode, $\mathrm{Cu}(\mathrm{II})$ may be less able to cycle back to $\mathrm{Cu}(\mathrm{I})$ (due to coordination of deprotonated amide), and thus produces less ROS. 


\subsection{Electrochemical Exploration of the Mechanism}

As phenH remains the most efficient ligand to slow down the ROS production induced by $\mathrm{Cu}(\mathrm{II})$, we decide to bring supplementary evidence to the mechanism presented in the introduction, using cyclic voltammetry experiments. Potentials are all given vs. SCE.

To study the redox activity of copper, the scanned potentials ranged from $0.5 \mathrm{~V}$ to $-0.8 \mathrm{~V}$ and back to $0.5 \mathrm{~V}$. The redox activity of phenH alone was first investigated: when scanning from $0.2 \mathrm{~V}$ to $-1 \mathrm{~V}$ and then to $1 \mathrm{~V}$, neither reduction nor oxidation wave can be seen: the cyclic voltammogram (CV) can be overlapped to the blank. PhenH has thus no redox activity in the potential window where the copper activity will be probed afterwards.

In a first experiment, a study at a single scan rate $(100 \mathrm{mV} / \mathrm{s})$ was carried out, where the ratio of phenH vs. $\mathrm{Cu}$ (II) (Figure 3a) was varied. In presence of 1 equivalent of phenH at $\mathrm{pH} 7.1$, the $\mathrm{CV}$ is characteristic of a quasi-reversible system, with $\mathrm{E}_{\mathrm{p}}{ }^{1 / 2}=-0.30 \mathrm{~V}$ and $\Delta \mathrm{E}_{\mathrm{p}}=0.16 \mathrm{~V}(\mathrm{E} 1)$. When the phenH to $\mathrm{Cu}$ ratio increases, the anodic wave at $-0.4 \mathrm{~V}$ is not modified, but the cathodic wave observed near $-0.3 \mathrm{~V}$ disappears while another one appears at $0.05 \mathrm{~V}$. This phenomenon could witness a so-called Chemical-Electrochemical mechanism where chemical reaction would be an equilibrium between the electro-generated $\mathrm{Cu}(\mathrm{I})(\mathrm{phenH})$ complex with a $\mathrm{Cu}(\mathrm{I})(\mathrm{phenH})_{2}$ complex $(\mathrm{C} 1)$, the first one being oxidized at $-0.3 \mathrm{~V}(\mathrm{E} 1)$, and the second one at $0.05 \mathrm{~V}$ (E2). This latter values is similar to that reported for the $\left[\mathrm{Cu}(\text { phen })_{2}\right]^{2+}$ complex [57].
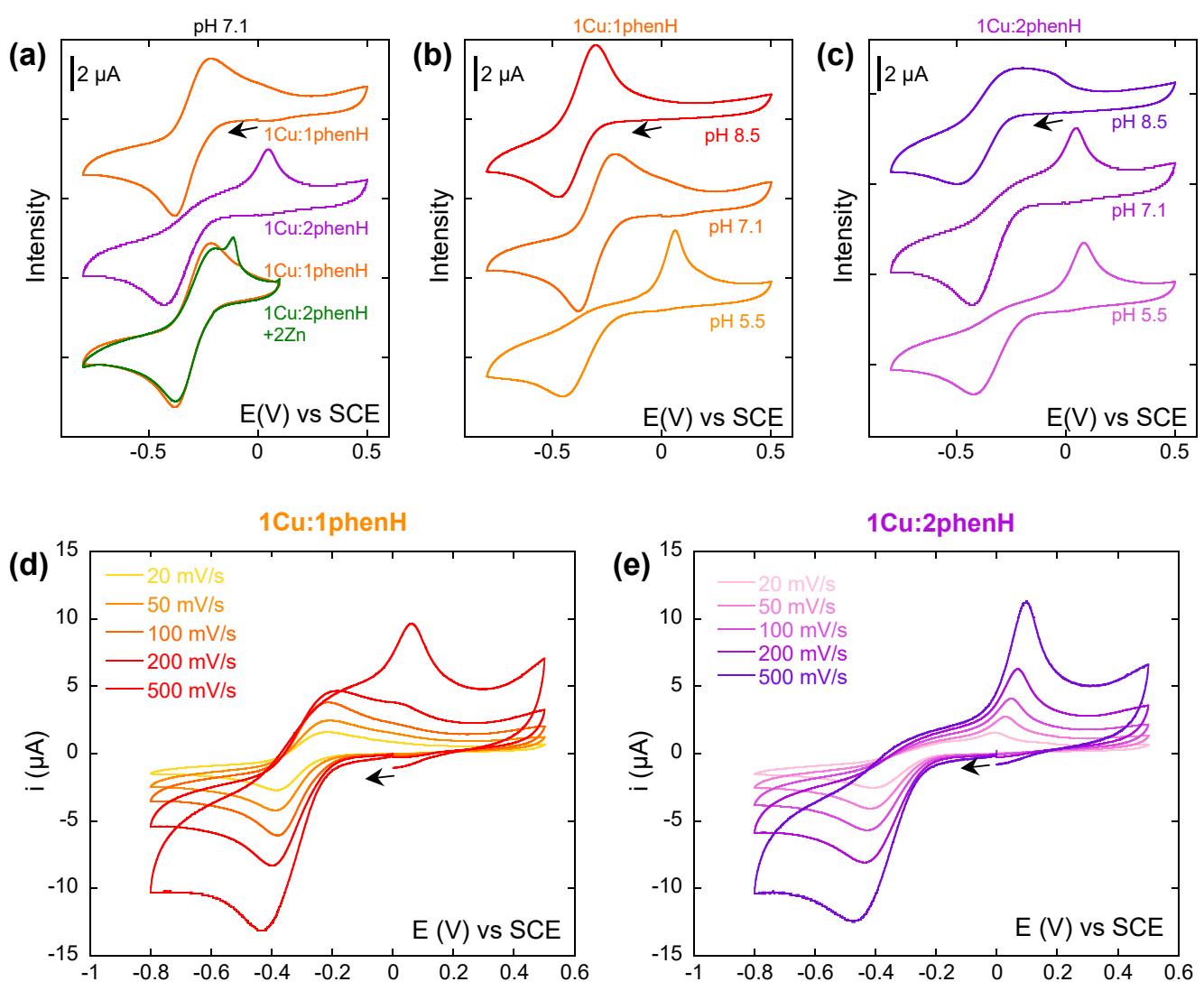

Figure 3. (a) Cyclic voltammograms of $\mathrm{Cu}$ in presence of 1 and 2 equivalents of phenH, and 2 equivalents of $\mathrm{Zn}(\mathrm{II})$. (b,c) Cyclic voltammograms of $\mathrm{Cu}$ in presence of 1 (b) or 2 (c) equivalents of phenH, at $\mathrm{pH}$ 5.5, 7.1 and 8.5. (d,e) Cyclic voltammograms of $\mathrm{Cu}$ in presence of 1 (d) or 2 (e) equivalents of phenH, depending on the scan rate. Scan rate: $100 \mathrm{mV} / \mathrm{s}$ unless stated otherwise. $[\mathrm{Cu}]=0.5 \mathrm{mM},[\mathrm{phenH}]=0.5$ and $1 \mathrm{mM},[\mathrm{Zn}(\mathrm{II})]=1 \mathrm{mM},[\mathrm{HEPES}]=50 \mathrm{mM}, \mathrm{pH} 7.1$ unless stated otherwise. Arrows indicate the starting potential and the direction of the scan. 


$$
\begin{gathered}
\mathrm{Cu}(\mathrm{II}) \mathrm{LH}_{-1}+\mathrm{e}^{-}+\mathrm{H}^{+} \rightleftarrows \mathrm{Cu}(\mathrm{I}) \mathrm{L} \\
\mathrm{Cu}(\mathrm{I}) \mathrm{L}+\mathrm{L}^{\prime}+\left(\mathrm{H}^{+}\right) \rightleftarrows \mathrm{Cu}(\mathrm{I}) \mathrm{L}_{2} \\
\mathrm{Cu}(\mathrm{I}) \mathrm{L}_{2}^{\prime} \rightarrow \mathrm{Cu}(\mathrm{II}) \mathrm{L}_{2}^{\prime}+\mathrm{e}^{-} \\
\mathrm{Cu}(\mathrm{II}) \mathrm{L}_{2}^{\prime} \rightarrow \mathrm{Cu}(\mathrm{II}) \mathrm{LH}_{-1}+\mathrm{L}^{\prime}+\mathrm{H}^{+}+\left(\mathrm{H}^{+}\right)
\end{gathered}
$$

$\mathrm{LH}_{-1}=\mathrm{L}$ with deprotonated amide $\mathrm{L}^{\prime}=\mathrm{L}$ or $\mathrm{LH}^{+}$(with protonated His)

The effect of ligand excess is abolished by the addition of $\mathrm{Zn}$ (II) in link with recruitment of excess ligand to form the $\mathrm{Zn}$ (II) complex as described in the introduction (Figure 3a green). On the CVs in presence of $\mathrm{Zn}(\mathrm{II})$, the sharp oxidation peak may come from the oxidation of solid $\mathrm{Cu}(0)$ that deposits at the surface of the electrode when scanning at the low potentials, indicating that $\mathrm{Zn}$ (II) can shift weak amount of $\mathrm{Cu}$ (I) outside the ligand.

To further explore the kinetics of the $\mathrm{CE}$ mechanism reactions, $\mathrm{Cu}(\mathrm{II})$ was then studied in presence of 1 and 2 equivalents of $\mathrm{phenH}$ while varying the scan rate at $\mathrm{pH} 7.1$ (Figure 3d,e). Strikingly with 1 equivalent of ligand, when the scan rate increases, the oxidation wave at $0.05 \mathrm{~V}$ appears, weak at a scan rate of $200 \mathrm{mV} / \mathrm{s}$, but predominant at $500 \mathrm{mV} / \mathrm{s}$. We propose that this equilibrium (reaction C1) is extremely quickly achieved and shifted to the formation of the $\mathrm{Cu}(\mathrm{I})(\mathrm{phenH})_{2}$ species. When the $\mathrm{CV}$ is performed at a scan rate of $500 \mathrm{mV} / \mathrm{s}$, it scans the system in a "frozen state" where $\mathrm{Cu}(\mathrm{I})(\mathrm{phenH})_{2}$ species are predominant, and thus only the oxidation wave at $0.05 \mathrm{~V}$ can be seen. When the scan rate decreases, when the potential reaches $-0.3 \mathrm{~V}$, the small proportion of $\mathrm{Cu}(\mathrm{I})(\mathrm{phenH})$ in solution is oxidized (so consumed), which shifts the equilibrium towards the formation of more $\mathrm{Cu}(\mathrm{I})(\mathrm{phenH})$, which still has the time to be oxidized. If the scan rate is slow enough (below $100 \mathrm{mV} / \mathrm{s}$ ), all $\mathrm{Cu}(\mathrm{I})(\text { phenH })_{2}$ is thus consumed before reaching $0.05 \mathrm{~V}$, and the oxidation wave at $0.05 \mathrm{~V}$ cannot be seen.

With 2 equivalents of ligand (Figure 3e), no difference could be seen on the different CVs while varying the scan rate (except the one due to the change of scan rate: higher intensity and shift of the waves). The equilibrium (C1) is shifted towards the formation of $\mathrm{Cu}(\mathrm{I})(\mathrm{phenH})_{2}$, so only the oxidation wave at $0.05 \mathrm{~V}$ is observed.

An important effect of the $\mathrm{pH}$ can be noticed on the $\mathrm{CV}$ with 1 and 2 equivalents of phenH (Figure $3 b, c)$. At 1 equivalent of phenH, when increasing the $\mathrm{pH}$ to 8.5 , the $\mathrm{CV}$ is characteristic of a reversible system, with $\mathrm{E}_{\mathrm{p}}{ }^{1 / 2}=-0.30 \mathrm{~V}$ and $\Delta \mathrm{E}_{\mathrm{p}}=0.16 \mathrm{~V}$, whereas when decreasing the $\mathrm{pH}$ to 5.5 , the $\mathrm{CV}$ exhibits the oxidation wave at $-0.05 \mathrm{~V}$, characteristic of the oxidation of $\mathrm{Cu}(\mathrm{I})(\mathrm{phenH})_{2}$. This can be explained by the state of protonation of the histidine during reaction $(\mathrm{C} 1)$ : in $\mathrm{Cu}(\mathrm{I})(\mathrm{phenH})$, the histidine must be deprotonated to form the complex, whereas in $\mathrm{Cu}(\mathrm{I})(\mathrm{phenH})_{2}$, it can be either protonated or deprotonated (Scheme 3). A more acidic medium thus shifts this equilibrium towards the formation of $\mathrm{Cu}(\mathrm{I})(\mathrm{phenH})_{2}$, and so the anodic wave at $0.05 \mathrm{~V}$ is observed, whereas a more basic medium shifts the equilibrium towards the formation of $\mathrm{Cu}(\mathrm{I})(\mathrm{phenH})$, thus showing the reversible process at $-0.3 \mathrm{~V}$. In presence of 2 equivalent of $\mathrm{phenH}$, a similar trend is observed but to a lesser extent, in line with the shift of the equilibrium $\mathrm{C} 1$ towards $\mathrm{Cu}(\mathrm{I})(\mathrm{phenH})_{2}$ in presence of 2 equivalent of ligand.

Previous electrochemical experiments led on phenH [39] are in agreement with the CVs obtained in this study. At $\mathrm{pH} 7.4$ and with a 1:1 ratio of $\mathrm{Cu}$ vs. phenH, a reduction wave at approximately $-0.4 \mathrm{~V}$ and an oxidation wave at $0.1 \mathrm{~V}$ were observed, corresponding to the oxidation of $\mathrm{Cu}(\mathrm{I})(\mathrm{phenH})_{2}$. The oxidation wave of $\mathrm{Cu}(\mathrm{I})(\mathrm{phenH})$ is not observed probably because of the different buffering conditions used in this study.

Cyclic voltammetry experiments in presence of the other ligands have also been conducted, at a 1:1 ratio of copper against the ligand (Figure S7). For phenHH and phenHGH, it is first noticeable that the reduction wave of $\mathrm{Cu}(\mathrm{II})$ is broader than that of phenH and happens between $-0.3 \mathrm{~V}$ and $-0.6 \mathrm{~V}$. This could be explained by the presence in solution of different $\mathrm{Cu}$ (II) species due to different speciation states (cf. Section 2.2) or protonation states (because of the second imidazole). These different states are in equilibrium one with another and have different reduction potentials. The oxidation potential of the electrogenerated $\mathrm{Cu}(\mathrm{I})$ species is at $0.1 \mathrm{~V}$, and the wave profile is very similar to the one encountered for the oxidation of the $\mathrm{Cu}(\mathrm{I})(\mathrm{phenH})_{2}$ species (Figure 3a). The equilibrium $(\mathrm{C})$ would thus be even more shifted towards $\mathrm{Cu}(\mathrm{I}) \mathrm{L}_{2}$ with the ligands 
phenHH and phenHGH. This is in line with the ROS experiments results: indeed, Cuinduced ROS production was faster in presence of phenHH or phenHGH than phenH, indicating the predominance of $\mathrm{Cu}(\mathrm{I}) \mathrm{L}_{2}$.

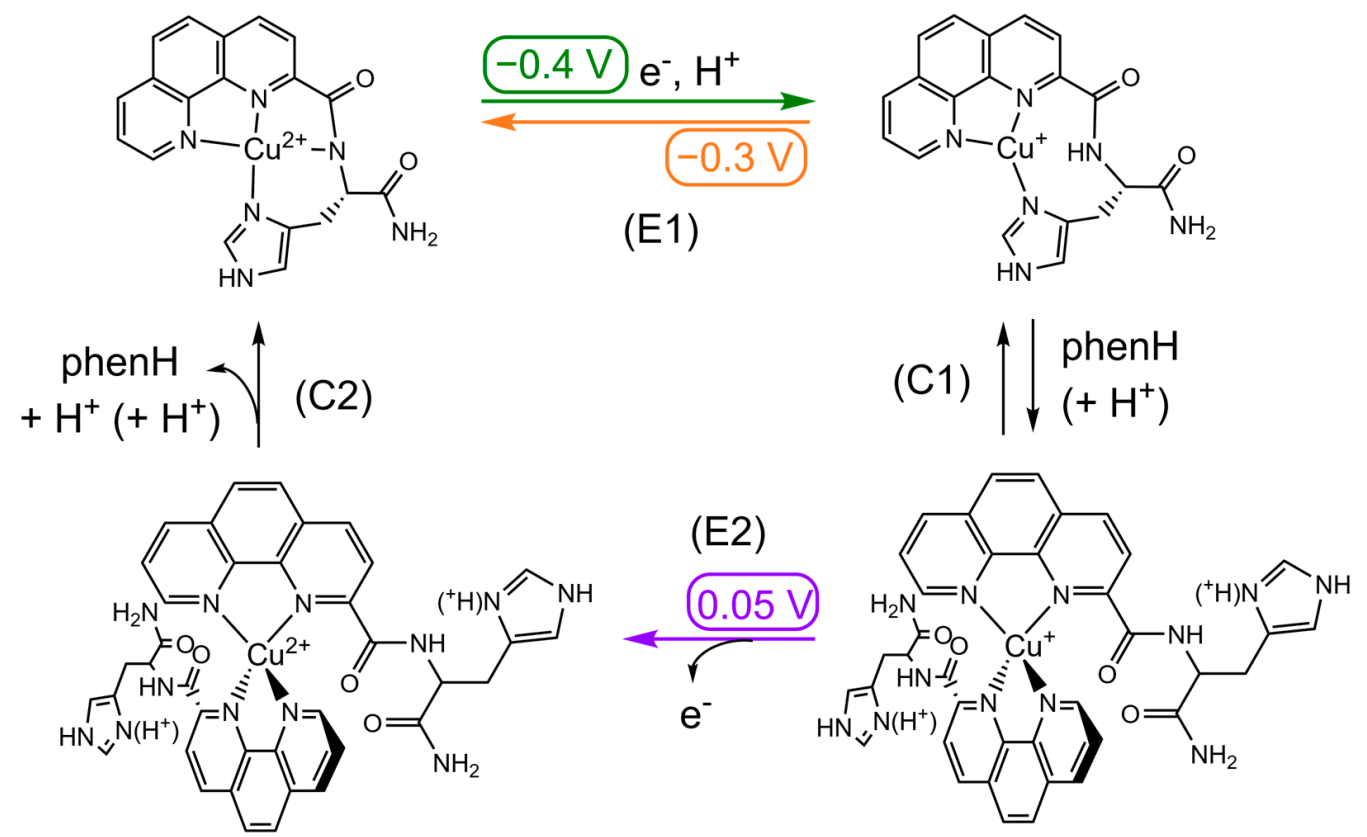

Scheme 3. Square-scheme of ECE mechanism of $\mathrm{Cu}$ in presence of phenH. Potentials are given in V vs. SCE.

Due to the poor solubility of $\mathrm{H}^{\prime}$ phenH' in water, this ligand was studied at $0.1 \mathrm{mM}$ with $1 \%$ methanol (instead of $0.5 \mathrm{mM}$ ) (Figure S7). The faradic contribution to the cyclic voltammograms is thus less important than with the previous ligands, and the signal/noise ratio is worse. The reduction wave of $\mathrm{Cu}$ (II) is observed at $-0.2 \mathrm{~V}$ : this higher value compared to previously described ligand could be due to the weaker stabilization of $\mathrm{Cu}$ (II) in water induced by $\mathrm{H}^{\prime}$ phen $\mathrm{H}^{\prime}$ than that of $\mathrm{phenH}$, because the metal is more loosely bound to the ligand and without participation of amide bond in its coordination (cf. Section 2.2). Similar to the other bis-histidine ligands, the process is not reversible, and the oxidation wave occurs at $0.2 \mathrm{~V}$. This higher anodic potential compared to phenH, phenHH and phenHGH could indicate that the complex $\mathrm{Cu}(\mathrm{I}) \mathrm{L}_{2}$ is more stable with $\mathrm{L}=\mathrm{H}^{\prime}$ phenH' than with $\mathrm{L}=$ phenHH or phenHGH. This is due to a weaker ability to generate the $\mathrm{Cu}(\mathrm{I})$ intermediate species, since the imidazole ring is farer (5-metallacycle vs. 8-metallacycle), and thus the $\mathrm{C} 1$ reaction is more shifted towards the $\mathrm{Cu}(\mathrm{I})\left(\mathrm{H}^{\prime} \mathrm{phenH}^{\prime}\right)_{2}$ species. The redox behavior is thus in line with the higher ascorbate consumption rate measured for $\mathrm{H}^{\prime} \mathrm{phenH}^{\prime}$.

\section{Conclusions}

In the present work, we have studied a wide family of phenanthroline-based peptide ligands in order to challenge the possibility of modifying the speciation at the $\mathrm{Cu}(\mathrm{I})$ level compared to a reference ligand, and thus improve its ability to lessen $\mathrm{Cu}$ and $\mathrm{Cu}-\mathrm{A} \beta$ induced ROS production, in the context of AD. First, ligands phenHH, phenHGH and $\mathrm{H}^{\prime}$ phenH' exhibited interesting $\mathrm{Cu}(\mathrm{II})$ coordination properties, especially in presence of more than one equivalent $\mathrm{Cu}$ (II). The formation of complexes with more than $1 \mathrm{Cu}$ (II) for 1 ligand is speculated, for instance $\mathrm{Cu}(\mathrm{II})_{2} \mathrm{~L}$ or $\mathrm{Cu}(\mathrm{II})_{3} \mathrm{~L}_{2}$, which is not observed with the parent phenH ligand. Second, with respect to $\mathrm{Cu}(\mathrm{I})$ speciation during the $\mathrm{ROS}$ production, the new ligands compare with the previously studied phenH, as probed by the monitoring of $\mathrm{Cu}$ and $\mathrm{Cu}-\mathrm{A} \beta$ ROS production at 1.2 and 2 equivalents of ligands. This indicates that neither the crowding of phen moiety nor the availability of two His groups to complete a 
tetrahedral coordination is sufficient to prevent the formation of $\mathrm{Cu}(\mathrm{I}) \mathrm{L}_{2}$. Other synthetic modifications are currently investigated to tackle this issue.

Lastly, the mechanism of redox cycling has been deeply probed by cyclic voltammetry for phenH in presence of $\mathrm{Cu}$ and $\mathrm{Zn}$, evidencing an equilibrium between the $\mathrm{Cu}(\mathrm{I})(\mathrm{phenH})$ or $\mathrm{Cu}(\mathrm{I})(\mathrm{phenH})_{2}$ species depending on the conditions (ratio Cu:ligand, presence of $\mathrm{Zn}$, $\mathrm{pH}$, scan rate). The other ligands have as well been studied, and in line with ROS data, the electrochemical study shows the predominance of the $\mathrm{Cu}(\mathrm{I}) \mathrm{L}_{2}$ species. Hence, the electrochemically-based mechanism perfectly matches the results obtained in the ROS production study.

\section{Materials and Methods}

\subsection{Materials}

All chemicals were purchased from Sigma-Aldrich, TCI Chemicals and Fluorochem and used without purification.

$\mathrm{A} \beta_{16}$ peptide (DAEFRHDSGYEVHHQK) was bought from Genecust.

Ligands phenH, phenHH, phenHGH and $\mathrm{H}^{\prime}$ phenH' were synthesized according to the protocols presented in the Supplementary Materials.

\subsection{Stock Solutions}

All the stock solutions (except $\mathrm{H}^{\prime}$ phenH') were prepared in Milli-Q water (resistivity: 18.2 M $\Omega . c m)$.

Sodium salt of 2-[4-(2-hydroxyethyl)piperazin-a-yl] ethanesulfonic (HEPES) acid buffer was prepared at an initial concentration of $500 \mathrm{mM}$, and its $\mathrm{pH}$ was adjusted at 7.1 with $5 \mathrm{M}$ sodium hydroxide solution.

$\mathrm{Cu}$ (II) stock solutions were prepared from $\mathrm{CuSO}_{4}, 5 \mathrm{H}_{2} \mathrm{O}$ at $100 \mathrm{mM}$ and were titrated using UV-vis spectroscopy $\left(\varepsilon_{800 \mathrm{~nm}}=12 \mathrm{M}^{-1} \mathrm{~cm}^{-1}\right)$.

$\mathrm{Zn}(\mathrm{II})$ stock solutions were prepared were prepared from $\mathrm{ZnSO}_{4}, \mathrm{H}_{2} \mathrm{O}$ at $100 \mathrm{mM}$.

$\mathrm{A} \beta$ stock solutions were prepared at $10 \mathrm{mM}$ and were titrated with UV-vis spectroscopy using the tyrosine chromophore $\left(\varepsilon_{276 \mathrm{~nm}}=1410 \mathrm{M}^{-1} \mathrm{~cm}^{-1}\right.$ in acidic conditions).

Ascorbate solutions were freshly prepared every week from sodium ascorbate at $5 \mathrm{mM}$.

PhenH, phenHH and phenHGH stock solutions were prepared at $10 \mathrm{mM}$ and their precise concentrations were determined at first using $\mathrm{Cu}(\mathrm{II})$ titration with a solution of known concentration using the ligand absorption of the complex. Molar absorption coefficients of the ligands were then measured, allowing a simpler titration of the ligand stock solutions. $\mathrm{H}^{\prime}$ phenH' $\mathrm{H}^{\prime}$ stock solutions were prepared in a similar way as the other ligands, but using methanol as solvent.

\subsection{Ascorbate Consumption Experiments}

UV-vis kinetic data of ascorbate consumption experiments were recorded with a Hewlett Packard Agilent 8453 spectrophotometer at a controlled temperature of $25^{\circ} \mathrm{C}$ in a $1 \mathrm{~cm}$ path length quartz cuvette, with $500 \mathrm{rpm}$ stirring.

The absorbance at $265 \mathrm{~nm}$ (ascorbate absorption band) was monitored every $30 \mathrm{~s}$, corrected by the absorbance at $800 \mathrm{~nm}$, and plotted as a function of time. The solutions were prepared in situ from stock solutions of $\mathrm{Cu}(\mathrm{II}), \mathrm{Zn}(\mathrm{II}), \mathrm{A} \beta$ and the ligands at $1 \mathrm{mM}$, and diluted to $12 \mu \mathrm{M}$ for $\mathrm{Zn}(\mathrm{II})$ and $\mathrm{A} \beta, 12$ or $24 \mu \mathrm{M}$ for the ligands, and $10 \mu \mathrm{M}$ for $\mathrm{Cu}(\mathrm{II})$, in $100 \mathrm{mM}$ HEPES buffer (pH 7.1). Ascorbate was freshly prepared and diluted to $100 \mu \mathrm{M}$. The final volume in the cuvette was adjusted to $2 \mathrm{~mL}$ with Milli-Q water.

Before each experiment, a blank with $100 \mathrm{mM}$ HEPES buffer was performed. Ascorbate was first added in the cuvette, $30 \mathrm{~s}$ later $\mathrm{Cu}$ (II) (and in some experiments $\mathrm{Zn}$ (II) and/or $\mathrm{A} \beta$ ) was added. When the absorbance reached 1.1, ligand was added.

Ascorbate consumption rate were calculated between 2000 and 3000 s, by dividing the slope of the variation of absorbance by the extinction coefficient of ascorbate, $\varepsilon_{265 \mathrm{~nm}}=14,500 \mathrm{M}^{-1} \mathrm{~cm}^{-1}$ [40]. Measurements were performed on at least two independent measurements. 


\subsection{Electron Paramagnetic Resonance Spectroscopy}

Electron paramagnetic resonance (EPR) spectra were recorded using an Elexsys E-500 Bruker spectrometer, operating at a microwave frequency of approximatively $9.5 \mathrm{GHz}$. Spectra were recorded using a microwave power of $5 \mathrm{~mW}$, with a magnetic field range of 2400 to $3700 \mathrm{G}$ and an amplitude modulation of $5 \mathrm{G}$, and with an attenuation of $16 \mathrm{~dB}$. Experiments were carried out at $117 \mathrm{~K}$ using a liquid nitrogen cryostat.

EPR samples were prepared in Eppendorf tubes from a $10 \mathrm{mM} \mathrm{Cu}(\mathrm{II})$ stock solution, diluted to $500 \mu \mathrm{M}$, in $50 \mathrm{mM}$ HEPES buffer ( $\mathrm{pH} 7.4$ ). Various equivalents of ligands ( 0.5 to 2) were added from $10 \mathrm{mM}$ stock solutions. As a cryoprotectant, $10 \%$ glycerol was added. The final volume was adjusted to $200 \mu \mathrm{L}$ with milli-Q water. The mixture was transferred in an EPR quartz tube and frozen in liquid nitrogen.

A blank spectrum with 50 mM HEPES buffer was also recorded and subtracted from the other samples' spectra.

\subsection{Cyclic Voltammetry}

Cyclic voltammetry (CV) experiments were performed using an Autolab PGSTAT302N potentiostat controlled with EC-Lab software. A three-electrode setup was used, consisting of a glassy carbon disk ( $3 \mathrm{~mm}$ in diameter), a saturated calomel electrode as reference electrode and a platinum wire as auxiliary electrode, in an argon-flushed $2 \mathrm{~mL}$ cell. The working electrode was carefully polished before each measurement on a red disk NAP (Struers) with $1 \mu \mathrm{m}$ AP-A suspension first, $0.3 \mu \mathrm{M}$ AP-A suspension then, during at least $5 \mathrm{~min}$ between each measurement. The solution was degassed during at least $5 \mathrm{~min}$ with argon between each measurement.

The scan rate was $100 \mathrm{mV} / \mathrm{s}$ unless indicated otherwise in the Figure's caption. Support electrolyte is the HEPES buffer. 3 scans were realized for each experiment, and unless stated otherwise, it is the first scan which is shown on the figures.

Before each experiment, a blank with 50 mM HEPES (pH 7.1) buffer was performed on a small range and on a large range of potential.

Supplementary Materials: The following are available online, Synthesis of the ligands and their precursors, Scheme S1: Synthesis scheme, Scheme S2: Proposed structures of the $\mathrm{Cu}$ (II) complexes with the ligands, Figure S1: EPR spectra of $\mathrm{Cu}(\mathrm{II})$ in the presence of 1 and 2 equivalents of ligand, Figure S2: Titration curves of the ligands by $\mathrm{Cu}(\mathrm{II})$, Figure S3: UV-vis and EPR spectra of the ligands in the presence of 1 and 2 equivalents of $\mathrm{Cu}(\mathrm{II})$, Figure S4: EPR spectra of $\mathrm{Cu}(\mathrm{II})$ in the presence of the ligands, $A \beta$ and $Z n(I I)$, Figure S5: Ascorbate consumption kinetics in the absence of $A \beta$, Figure S6: EPR spectra of $\mathrm{Cu}(\mathrm{II})$ with $\mathrm{H}^{\prime}$ phen $\mathrm{H}^{\prime}$ and $\mathrm{Zn}(\mathrm{II})$, Figure S7: Cyclic voltammograms of $\mathrm{Cu}$ in presence of 1 equivalent of the ligands, Table S1: UV-visible and EPR parameters of the ligands in presence of 1 or 2 equivalents of $\mathrm{Cu}(\mathrm{II})$.

Author Contributions: Conceptualization: C.E. and C.H.; Investigation: M.D.; Supervision: C.R., C.E. and C.H.; Validation: C.E. and C.H.; Visualization: M.D.; Writing—original draft: M.D.; Writingreview and editing: M.D., C.R., C.E. and C.H. All authors have read and agreed to the published version of the manuscript.

Funding: ERC StG 638712 and ANR Copperation are acknowledged for financial support. The Ecole normale supérieure PSL is acknowledged for M.D.'s PhD grant.

Institutional Review Board Statement: Not applicable.

Informed Consent Statement: Not applicable.

Data Availability Statement: The date are available on request from the corresponding author.

Acknowledgments: C.H. and C.E. thank Olga Iranzo for fruitful discussions. Lionel Rechignat is acknowledged for recording EPR data and Karine Reybier is acknowledged for the access to EPR facilities. Patrick Kyangwi Malikidogo is warmly acknowledged for his help in peptide synthesis.

Conflicts of Interest: The authors declare no conflict of interest.

Sample Availability: Samples of the compounds are available from the authors. 


\section{References}

1. Alzheimer's Association. 2017 Alzheimer's disease facts and figures. Alzheimer's Dement. 2017, 13, 325-373. [CrossRef]

2. Alzheimer's Disease International. World Alzheimer Report 2015, The Global Impact of Dementia: An Analysis of Prevalence, Incidence, Cost and Trends; Alzheimer's Disease International: London, UK, 2015.

3. Cheignon, C.; Tomas, M.; Bonnefont-Rousselot, D.; Faller, P.; Hureau, C.; Collin, F. Oxidative stress and the amyloid beta peptide in Alzheimer's disease. Redox Biol. 2018, 14, 450-464. [CrossRef]

4. Hardy, J.; Higgins, G. Alzheimer's disease: The amyloid cascade hypothesis. Science 1992, 256, 184-185. [CrossRef]

5. Selkoe, D.J.; Hardy, J. The amyloid hypothesis of Alzheimer's disease at 25 years. EMBO Mol. Med. 2016, 8, 595-608. [CrossRef]

6. Atrián-Blasco, E.; Gonzalez, P.; Santoro, A.; Alies, B.; Faller, P.; Hureau, C. Cu and Zn coordination to amyloid peptides: From fascinating chemistry to debated pathological relevance. Coord. Chem. Rev. 2018, 371, 38-55. [CrossRef]

7. Ahmad, W.; Ijaz, B.; Shabbiri, K.; Ahmed, F.; Rehman, S. Oxidative toxicity in diabetes and Alzheimer's disease: Mechanisms behind ROS/RNS generation. J. Biomed. Sci. 2017, 24, 76. [CrossRef]

8. Lee, S.J.C.; Nam, E.; Lee, H.J.; Savelieff, M.G.; Lim, M.H. Towards an understanding of amyloid- $\beta$ oligomers: Characterization, toxicity mechanisms, and inhibitors. Chem. Soc. Rev. 2017, 46, 310-323. [CrossRef]

9. Liu, Y.; Nguyen, M.; Robert, A.; Meunier, B. Metal ions in Alzheimer's disease: A key role or not? Acc. Chem. Res. 2019, 52, 2026-2035. [CrossRef]

10. Savelieff, M.G.; Lee, S.; Liu, Y.; Lim, M.H. Untangling amyloid- $\beta$, tau, and metals in Alzheimer's disease. ACS Chem. Biol. 2013, 8 , 856-865. [CrossRef]

11. Hureau, C. Metal ions and complexes in Alzheimer's disease: From fundamental to therapeutic perspectives. In Encyclopedia of Inorganic and Bioinorganic Chemistry; Scott, R.A., Ed.; John Wiley \& Sons: Chichester, UK, 2018; pp. 1-14.

12. Cheignon, C.; Jones, M.; Atrián-Blasco, E.; Kieffer, I.; Faller, P.; Collin, F.; Hureau, C. Identification of key structural features of the elusive $\mathrm{Cu}-\mathrm{A} \beta$ complex that generates ROS in Alzheimer's disease. Chem. Sci. 2017, 8, 5107-5118. [CrossRef]

13. Faller, P.; Hureau, C.; Berthoumieu, O. Role of metal ions in the self-assembly of the Alzheimer's amyloid- $\beta$ peptide. Inorg. Chem. 2013, 52, 12193-12206. [CrossRef]

14. Alies, B.; Renaglia, E.; Rózga, M.; Bal, W.; Faller, P.; Hureau, C. Cu(II) affinity for the Alzheimer's peptide: Tyrosine fluorescence studies revisited. Anal. Chem. 2013, 85, 1501-1508. [CrossRef]

15. Barnham, K.J.; Bush, A.I. Biological metals and metal-targeting compounds in major neurodegenerative diseases. Chem. Soc. Rev. 2014, 43, 6727-6749. [CrossRef]

16. Drew, S.C.; Barnham, K.J. The heterogeneous nature of $\mathrm{Cu}\left({ }^{2+}\right)$ interactions with Alzheimer's amyloid- $\beta$ peptide. Acc. Chem. Res. 2011, 44, 1146-1155. [CrossRef]

17. Kozlowski, H.; Luczkowski, M.; Remelli, M.; Valensin, D. Copper, zinc and iron in neurodegenerative diseases (Alzheimer's disease, Parkinson's disease and prion diseases). Coord. Chem. Rev. 2012, 256, 2129-2141. [CrossRef]

18. Budimir, A. Metal ions, Alzheimer's disease and chelation therapy. Acta Pharm. 2011, 61, 1-14. [CrossRef]

19. Nam, G.; Lim, M.H. Intertwined pathologies of amyloid- $\beta$ and metal ions in Alzheimer's disease: Metal-amyloid- $\beta$. Chem. Lett. 2019, 48, 951-960. [CrossRef]

20. Farkas, E.; Sóvágó, I. Metal complexes of amino acids and peptides. In Amino Acids, Peptides and Proteins; Ryadnov, M., Hudecz, F., Eds.; Royal Society of Chemistry: Cambridge, UK, 2016; Volume 41, pp. 100-151.

21. Greenough, M.A.; Camakaris, J.; Bush, A.I. Metal dyshomeostasis and oxidative stress in Alzheimer's disease. Neurochem. Int. 2013, 62, 540-555. [CrossRef]

22. Pohanka, M. Alzheimer's disease and oxidative stress: A review. CMC 2013, 21, 356-364. [CrossRef]

23. Kepp, K.P. Alzheimer's disease: How metal ions define $\beta$-amyloid function. Coord. Chem. Rev. 2017, 351, 127-159. [CrossRef]

24. Solomon, E.I.; Heppner, D.E.; Johnston, E.M.; Ginsbach, J.W.; Cirera, J.; Qayyum, M.; Kieber-Emmons, M.T.; Kjaergaard, C.H.; Hadt, R.G.; Tian, L. Copper active sites in biology. Chem. Rev. 2014, 114, 3659-3853. [CrossRef]

25. Faller, P.; Hureau, C.; La Penna, G. Metal ions and intrinsically disordered proteins and peptides: From Cu/Zn amyloid- $\beta$ to general principles. Acc. Chem. Res. 2014, 47, 2252-2259. [CrossRef]

26. Savelieff, M.G.; Nam, G.; Kang, J.; Lee, H.J.; Lee, M.; Lim, M.H. Development of multifunctional molecules as potential therapeutic candidates for Alzheimer's disease, Parkinson's disease, and amyotrophic lateral sclerosis in the last decade. Chem. Rev. 2019, 119, 1221-1322. [CrossRef] [PubMed]

27. Esmieu, C.; Guettas, D.; Conte-Daban, A.; Sabater, L.; Faller, P.; Hureau, C. Copper-targeting approaches in Alzheimer's disease: How to improve the fallouts obtained from in vitro studies. Inorg. Chem. 2019, 58, 13509-13527. [CrossRef] [PubMed]

28. Robert, A.; Liu, Y.; Nguyen, M.; Meunier, B. Regulation of copper and iron homeostasis by metal chelators: A possible chemotherapy for Alzheimer's disease. Acc. Chem. Res. 2015, 48, 1332-1339. [CrossRef] [PubMed]

29. Conte-Daban, A.; Borghesani, V.; Sayen, S.; Guillon, E.; Journaux, Y.; Gontard, G.; Lisnard, L.; Hureau, C. Link between affinity and $\mathrm{Cu}(\mathrm{II})$ binding sites to amyloid- $\beta$ peptides evaluated by a new water-soluble UV-visible ratiometric dye with a moderate $\mathrm{Cu}$ (II) affinity. Anal. Chem. 2017, 89, 2155-2162. [CrossRef]

30. Alies, B.; Badei, B.; Faller, P.; Hureau, C. Reevaluation of copper(I) affinity for amyloid- $\beta$ peptides by competition with ferrozineAn unusual copper(I) indicator. Chem. Eur. J. 2012, 18, 1161-1167. [CrossRef] [PubMed] 
31. Xiao, Z.; Gottschlich, L.; van der Meulen, R.; Udagedara, S.R.; Wedd, A.G. Evaluation of quantitative probes for weaker Cu(I) binding sites completes a set of four capable of detecting $\mathrm{Cu}(\mathrm{I})$ affinities from nanomolar to attomolar. Metallomics $2013,5,501$. [CrossRef]

32. Young, T.R.; Kirchner, A.; Wedd, A.G.; Xiao, Z. An integrated study of the affinities of the A $\beta 16$ peptide for $\mathrm{Cu}(\mathrm{I})$ and $\mathrm{Cu}(\mathrm{II})$ : Implications for the catalytic production of reactive oxygen species. Metallomics 2014, 6, 505-517. [CrossRef]

33. Xiao, Z.; Donnelly, P.S.; Zimmermann, M.; Wedd, A.G. Transfer of copper between bis(thiosemicarbazone) ligands and intracellular copper-binding proteins. Insights into mechanisms of copper uptake and hypoxia selectivity. Inorg. Chem. 2008, 47, 4338-4347. [CrossRef]

34. Atrián-Blasco, E.; Conte-Daban, A.; Hureau, C. Mutual interference of Cu and Zn ions in Alzheimer's disease: Perspectives at the molecular level. Dalton Trans. 2017, 46, 12750-12759. [CrossRef] [PubMed]

35. Stuerenburg, H.J. CSF copper concentrations, blood-brain barrier function, and coeruloplasmin synthesis during the treatment of Wilson's disease. J. Neural Transm. 2000, 107, 321-329. [CrossRef]

36. Sensi, S.L.; Paoletti, P.; Bush, A.I.; Sekler, I. Zinc in the physiology and pathology of the CNS. Nat. Rev. Neurosci. 2009, 10, 780-791. [CrossRef]

37. Conte-Daban, A.; Beyler, M.; Tripier, R.; Hureau, C. Kinetics are crucial when targeting copper ions to fight Alzheimer's disease: An illustration with azamacrocyclic ligands. Chem. Eur. J. 2018, 24, 8447-8452. [CrossRef] [PubMed]

38. Esmieu, C.; Balderrama-Martínez-Sotomayor, R.; Conte-Daban, A.; Iranzo, O.; Hureau, C. Unexpected trends in copper removal from A $\beta$ peptide: When less ligand is better and Zn helps. Inorg. Chem. 2021, 60, 1248-1256. [CrossRef]

39. Leite, S.M.G.; Lima, L.M.P.; Gama, S.; Mendes, F.; Orio, M.; Bento, I.; Paulo, A.; Delgado, R.; Iranzo, O. Copper(II) complexes of phenanthroline and histidine containing ligands: Synthesis, characterization and evaluation of their DNA cleavage and cytotoxic activity. Inorg. Chem. 2016, 55, 11801-11814. [CrossRef]

40. Atrián-Blasco, E.; del Barrio, M.; Faller, P.; Hureau, C. Ascorbate oxidation by Cu(amyloid- $\beta$ ) complexes: Determination of the intrinsic rate as a function of alterations in the peptide sequence revealing key residues for reactive oxygen species production. Anal. Chem. 2018, 90, 5909-5915. [CrossRef] [PubMed]

41. Sun, W.-H.; Jie, S.; Zhang, S.; Zhang, W.; Song, Y.; Ma, H.; Chen, J.; Wedeking, K.; Fröhlich, R. Iron complexes bearing 2imino-1,10-phenanthrolinyl ligands as highly active catalysts for ethylene oligomerization. Organometallics 2006, 25, 666-677. [CrossRef]

42. Chan, W.; White, P. (Eds.) Fmoc Solid Phase Peptide Synthesis: A Practical Approach; Oxford University Press: Oxford, UK, 1999.

43. Eissler, S.; Kley, M.; Bächle, D.; Loidl, G.; Meier, T.; Samson, D. Substitution determination of Fmoc-substituted resins at different wavelengths: Substitution determination of Fmoc-substituted resins. J. Pept. Sci. 2017, 23, 757-762. [CrossRef]

44. Xiao, C.-L.; Wang, C.-Z.; Yuan, L.-Y.; Li, B.; He, H.; Wang, S.; Zhao, Y.-L.; Chai, Z.-F.; Shi, W.-Q. Excellent selectivity for actinides with a tetradentate 2,9-diamide-1,10-phenanthroline ligand in highly acidic solution: A hard-soft donor combined strategy. Inorg. Chem. 2014, 53, 1712-1720. [CrossRef]

45. Kaye, P.T.; Wellington, K.W. Designer ligands. VI. Synthesis of 1,10-phenanthroline-based polydentate ligands. Synth. Commun. 2001, 31, 799-804. [CrossRef]

46. Sigel, H.; Martin, R.B. Coordinating properties of the amide bond. stability and structure of metal ion complexes of peptides and related ligands. Chem. Rev. 1982, 82, 385-426. [CrossRef]

47. Peisach, J.; Blumberg, W.E. Structural implications derived from the analysis of electron paramagnetic resonance spectra of natural and artificial copper proteins. Arch. Biochem. Biophys. 1974, 165, 691-708. [CrossRef]

48. Rasia, R.M.; Bertoncini, C.W.; Marsh, D.; Hoyer, W.; Cherny, D.; Zweckstetter, M.; Griesinger, C.; Jovin, T.M.; Fernandez, C.O. Structural characterization of copper(II) binding to $\alpha$-synuclein: Insights into the bioinorganic chemistry of Parkinson's disease. Proc. Natl. Acad. Sci. USA 2005, 102, 4294-4299. [CrossRef]

49. Housecroft, C.E.; Sharpe, A.G. Inorganic Chemistry, 4th ed.; Pearson: Harlow, UK; New York, NY, USA, 2012.

50. Sóvágó, I.; Kállay, C.; Várnagy, K. Peptides as complexing agents: Factors influencing the structure and thermodynamic stability of peptide complexes. Coord. Chem. Rev. 2012, 256, 2225-2233. [CrossRef]

51. Conte-Daban, A.; Boff, B.; Candido Matias, A.; Montes Aparicio, C.N.; Gateau, C.; Lebrun, C.; Cerchiaro, G.; Kieffer, I.; Sayen, S.; Guillon, E.; et al. A trishistidine pseudopeptide with ability to remove both $\mathrm{Cu}(\mathrm{I})$ and $\mathrm{Cu}(\mathrm{II})$ from the Alzheimer's peptide and to stop the associated ROS formation. Chem. Eur. J. 2017, 23, 17078-17088. [CrossRef]

52. Chassaing, S.; Collin, F.; Dorlet, P.; Gout, J.; Hureau, C.; Faller, P. Copper and heme-mediated abeta toxicity: Redox chemistry, abeta oxidations and anti-ROS compounds. CTMC 2013, 12, 2573-2595. [CrossRef] [PubMed]

53. Alies, B.; Sasaki, I.; Proux, O.; Sayen, S.; Guillon, E.; Faller, P.; Hureau, C. Zn impacts Cu coordination to amyloid- $\beta$, the Alzheimer's peptide, but not the ROS production and the associated cell toxicity. Chem. Commun. 2013, 49, 1214. [CrossRef]

54. Crnich, E.; Lullo, R.; Tabaka, A.; Havens, M.A.; Kissel, D.S. Interactions of copper and copper chelate compounds with the amyloid beta peptide: An investigation into electrochemistry, reactive oxygen species and peptide aggregation. J. Inorg. Biochem. 2021, 222, 111493. [CrossRef]

55. Gardiner, B.; Dougherty, J.A.; Ponnalagu, D.; Singh, H.; Angelos, M.; Chen, C.-A.; Khan, M. Measurement of oxidative stress markers in vitro using commercially available kits. In Measuring Oxidants and Oxidative Stress in Biological Systems; Berliner, L.J., Parinandi, N.L., Eds.; Springer: Cham, Switzerland, 2020; Volume 34, pp. 39-60. 
56. Mital, M.; Wezynfeld, N.E.; Frączyk, T.; Wiloch, M.Z.; Wawrzyniak, U.E.; Bonna, A.; Tumpach, C.; Barnham, K.J.; Haigh, C.L.; Bal, W.; et al. A functional role for $\mathrm{A} \beta$ in metal homeostasis? N-truncation and high-affinity copper binding. Angew. Chem. Int. Ed. 2015, 54, 10460-10464. [CrossRef]

57. James, B.R.; Williams, R.J.P. The oxidation-reduction potentials of some copper complexes. J. Chem. Soc. 1961, 2007-2019. [CrossRef] 